\title{
Geochemistry of the Um Had Plutonites, Central Eastern Desert, Egypt: Implications for Magma Evolution, and Tectonic Setting
}

\author{
Nedal Qaoud ${ }^{1}$ \\ ${ }^{1}$ Geology Department, Faculty of Science, Al-Azhar University, Gaza, Palestine \\ Correspondence: Nedal Qaoud, Geology Department, Faculty of Science, Al-Azhar University, Gaza, Palestine. \\ E-mail: nedalqaoud@hotmail.com
}

Received: January 7, 2014 Accepted: January 20, 2014 Online Published: April 23, 2014

doi:10.5539/jgg.v6n2p36 URL: http://dx.doi.org/10.5539/jgg.v6n2p36

\begin{abstract}
Geochemistry of gabbroid and granitoid plutonites from the Um Had area indicates island arc subalkaline basic magma with tholeiitic affinity and calc-alkaline, metaluminous and slightly peraluminous magma, respectively. Although different in age both plutonite types were emplaced under compressional regime, where subduction-related environment was dominant. They were formed under relatively low to moderate water-vapour pressure (1-5 k-bars) at moderate depths $(20-30 \mathrm{~km})$. Biotite granites were formed at a relatively high temperature range $\left(800-840{ }^{\circ} \mathrm{C}\right)$, while biotite-muscovite granites were formed under relatively moderate temperature conditions $\left(760-800{ }^{\circ} \mathrm{C}\right)$. These two units may represent evolution from island arc to active continental margin. It is suggested that island arc gabbros might have sourced the late subduction-related calc-alkaline granitoids during the waning stages of the pan-African orogeny. The I-type nature of the investigated plutonites in the study area and elsewhere suggests the juvenile character of the basement complex of the Eastern Desert of Egypt.
\end{abstract}

\section{Introduction}

The Pan-African basement of the Eastern Desert of Egypt is composed mainly of: 1) island arc assemblage (850 -614 Ma; Kröner et al., 1992; Stern, 1981; Stern \& Hedge, 1985); 2) ophiolitic sequences (810-730 Ma; Kröner et al., 1992); 3) older granitoids (750-610 Ma; Hashad, 1980; Mogahzi, 1999; Stern \& Hedge, 1985); 4) Dokhan volcanic suite (630-580 Ma; Stern \& Hedge, 1985; Abdel-Rahman \& Doig, 1987; Stern \& Gottfried, 1986; Wilde \& Youssef, 2000; Breitkreuz et al., 2010); 5) molasse-type Hammamat sediments (610-585 Ma; Wilde \& Youssef, 2002; Willis et al., 1988), and 6) younger granitoids (610-550 Ma; Stern \& Hedge, 1985; Mogahzi, 1999; Moussa et al., 2008).

Speculation concerning the origin of the younger granitoids in the Nubian Shield is the case. These granitoids have been considered either as the fractionated end-members of calc-alkaline magmas (e.g., Rogers and Greenberg, 1981) or as the initial expression of withinplate magmatism (e.g., Harris \& Marriner, 1980). Sr, Nd and $\mathrm{Pb}$ isotopic systematics emphasise on the generation of the younger granitoids by anatexis of older tonalite granodiorite suites (740-610 Ma) and subsequently subjected to an episode of metasomatism of basic magma (e.g., Gillespie and Dixon, 1983) or assimilation of older crustal components (e.g., Bickford et al., 1989; Sultan et al., 1990) as well as by fractionation of mafic melts (e.g., El-Sayed, 1998; El-Sayed et al., 2002).

In this study, the geochemical characteristics of the Um Had-Um Shegila plutonites are addressed to clarify the tectonic environment that the Central Eastern Desert represents.

\section{The Um Had Granitoids}

The Um Had area contains a large elliptical structure trending northwest outlining a core of medium- to high-grade partly gneissic rocks enclosed by a domed thick mylonitic shear zone (e.g., Fowler, 2001; Figure 1). The core is up-heaved by the Um Had granitoid intrusion. The latter and its equivalents scattered throughout the Egyptian Eastern Desert was emplaced during Pan-African orogeny. These granitoids are referred to as late- to post-orogenic calc-alkaline to transitional A-type granitoids, interpreted by Black and Liegeois (1993) as being the result of delamination of the continental lithospheric mantle following the tectonic collisions of East and West Gondwana. These granitoids are characterised by unfoliated, small, nearly circular to elongate epizonal plutons with sharp intrusive contacts. 
The southern, SW and SE contacts of this intrusion dip generally at moderate angles outwards, whereas, the western and eastern contacts are steep and associated with syn-intrusion faulting. On the other hand, the northern edge is defined by the northernmost significant dykes cropping out along Wadi Shegila.

\section{Methods}

Thirty seven samples (23 from the granitoid rocks and 14 from the gabbroic rocks) were carefully selected for the chemical analyses to avoid the effects of secondary alteration. The samples were then submitted to ACME Analytical Labs ltd. (Canada). Major element data were acquired using X-ray fluorescence spectrometry (XRF) on fused beads and pressed pellets. Trace element data, including rare earth-elements (REE) were obtained using Inductively Coupled Plasma Mass Spectrometry (ICP-MS). Based on replicate analyses and international standards, the precision is better than $\pm 1 \%$ for major elements, and $\pm 5 \%$ for most trace elements. Data of chemical analyses are illustrated in (Tables 1 and 2).

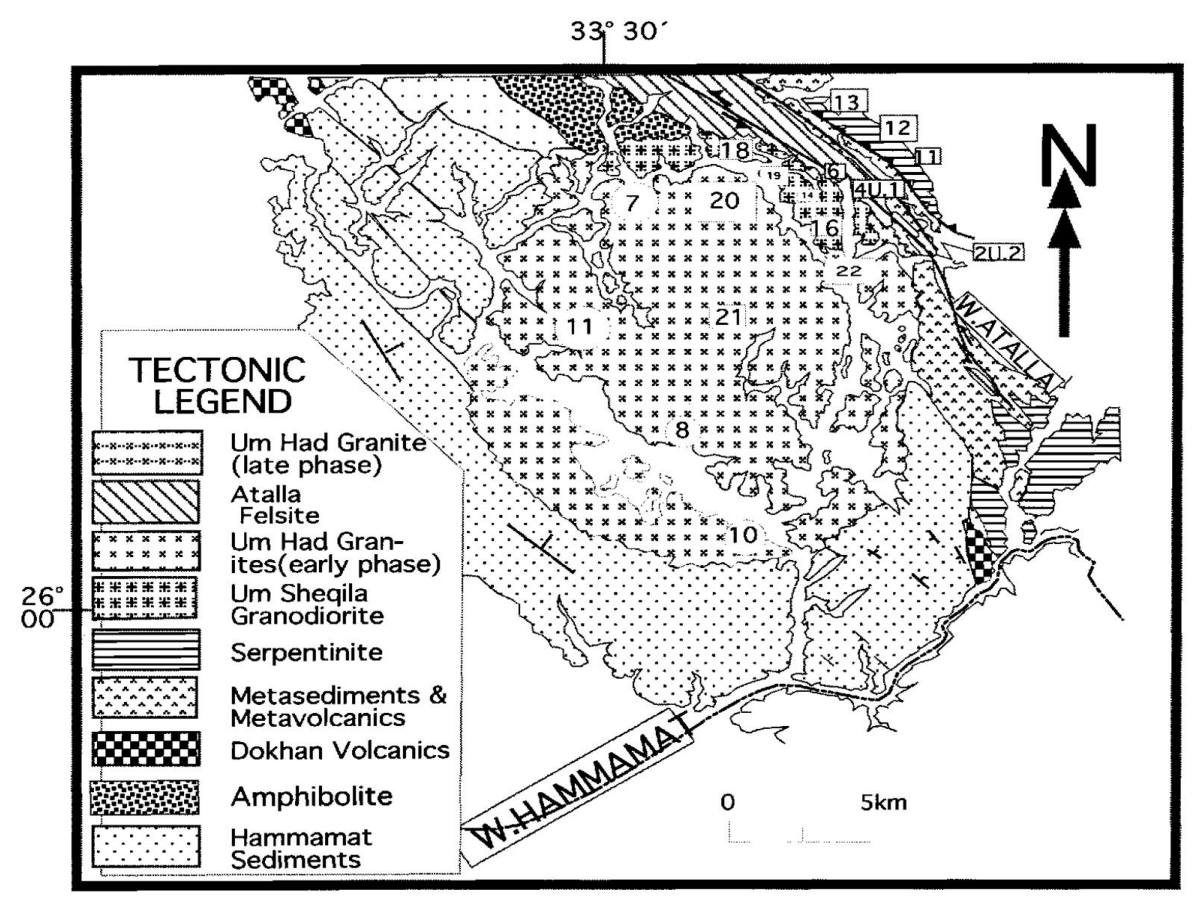

Figure 1. Geological map of the Urn Had granitoid intrusion, Central Eastern Desert of Egypt

Table 1. Major oxides and trace elements of granitoid rocks, Um Had area (Table 1a, Table 1b)

Table 1a. Major oxides and trace elements of granitoid rocks, Um Had area (Pink granite)

\begin{tabular}{|c|c|c|c|c|c|c|c|c|c|}
\hline & \multicolumn{9}{|c|}{ Pink granite } \\
\hline & 1 & 2 & 3 & 4 & 5 & 6 & 7 & 8 & 9 \\
\hline \multicolumn{10}{|c|}{ Major and minor Oxides } \\
\hline $\mathrm{SiO}_{2}$ & 74.13 & 74.91 & 75.91 & 73.33 & 76.24 & 74.79 & 75.21 & 74.39 & 73.19 \\
\hline $\mathrm{TiO}_{2}$ & 0.14 & 0.17 & 0.18 & 0.17 & 0.21 & 0.39 & 0.24 & 0.31 & 0.17 \\
\hline $\mathrm{Al}_{2} \mathrm{O}_{3}$ & 13.93 & 13.24 & 12.91 & 14.39 & 12.93 & 13.96 & 14.21 & 13.92 & 14.11 \\
\hline $\mathrm{Fe}_{2} \mathrm{O}_{3}$ & 0.91 & 0.89 & 0.93 & 1.01 & 0.88 & 0.93 & 0.83 & 0.93 & 0.91 \\
\hline $\mathrm{FeO}$ & 0.11 & 0.13 & 0.14 & 0.31 & 0.13 & 0.17 & 0.19 & 0.21 & 0.34 \\
\hline $\mathrm{MnO}$ & 0.13 & 0.07 & 0.1 & 0.07 & 0.08 & 0.09 & 0.03 & 0.04 & 0.07 \\
\hline $\mathrm{MgO}$ & 0.09 & 0.19 & 0.12 & 0.13 & 0.14 & 0.15 & 0.13 & 0.12 & 0.12 \\
\hline $\mathrm{CaO}$ & 1.25 & 1.29 & 1.11 & 1.18 & 1.12 & 1.19 & 1.19 & 1.71 & 1.18 \\
\hline $\mathrm{Na}_{2} \mathrm{O}$ & 3.78 & 3.91 & 3.89 & 3.41 & 4.12 & 3.76 & 4.13 & 4.15 & 3.78 \\
\hline
\end{tabular}




\begin{tabular}{|c|c|c|c|c|c|c|c|c|c|}
\hline $\mathrm{K}_{2} \mathrm{O}$ & 4.29 & 5.21 & 3.18 & 3.78 & 4.92 & 5.21 & 5.34 & 4.15 & 4.77 \\
\hline $\mathrm{P}_{2} \mathrm{O}_{5}$ & 0.04 & 0.04 & 0.04 & 0.05 & 0.01 & 0.02 & 0.09 & 0.04 & 0.03 \\
\hline $\mathrm{H}_{2} \mathrm{O}$ & 1.51 & 1.34 & 1.23 & 1.79 & 0.89 & 0.14 & 0.13 & 0.43 & 0.91 \\
\hline \multicolumn{10}{|c|}{ Trace elements } \\
\hline $\mathrm{Ba}$ & 340 & 352 & 594 & 456 & 458 & 459 & 354 & 148 & 254 \\
\hline $\mathrm{Rb}$ & 56 & 54 & 58 & 64 & 67 & 59 & 75 & 48 & 67 \\
\hline $\mathrm{Sr}$ & 364 & 358 & 487 & 256 & 398 & 371 & 458 & 287 & 264 \\
\hline $\mathrm{Ga}$ & 16 & 15 & 17 & 10 & 16 & 18 & 14 & 13 & 12 \\
\hline $\mathrm{Nb}$ & 11 & 14 & 16 & 18 & 10 & 13 & 14 & 11 & 12 \\
\hline $\mathrm{Zr}$ & 124 & 156 & 187 & 100 & 147 & 198 & 132 & 150 & 175 \\
\hline $\mathrm{Y}$ & 10 & 12 & 18 & 16 & 12 & 17 & 12 & 17 & 15 \\
\hline Th & 6 & 5 & 8 & 2 & - & 4 & - & 2 & 4 \\
\hline U & 2 & 2.4 & 2.5 & 2 & 2 & 2.1 & 2.1 & 2 & 2.4 \\
\hline $\mathrm{Ni}$ & 24 & 45 & 35 & 25 & 27 & 12 & 40 & 35 & 39 \\
\hline $\mathrm{Cu}$ & 22 & 24 & 11 & 16 & 25 & 14 & 19 & 27 & 35 \\
\hline $\mathrm{V}$ & 54 & 76 & 49 & 53 & 59 & 80 & 57 & 49 & 20 \\
\hline $\mathrm{Zn}$ & 61 & 67 & 75 & 59 & 64 & 68 & 59 & 57 & 63 \\
\hline $\mathrm{La}$ & 15 & 11 & 17 & 10 & 19 & 16 & 17 & 10 & 9 \\
\hline $\mathrm{Ce}$ & 24 & 29 & 45 & 37 & 45 & 26 & 34 & 38 & 47 \\
\hline $\mathrm{Nd}$ & 18 & 16 & 10 & 17 & 13 & 24 & 15 & 18 & 11 \\
\hline
\end{tabular}

Table 1b. Major oxides and trace elements of granitoid rocks, Um Had area (Biotite granite)

\begin{tabular}{|c|c|c|c|c|c|c|c|c|c|c|c|c|c|c|}
\hline & \multicolumn{14}{|c|}{ Biotite granite } \\
\hline & 1 & 2 & 3 & 4 & 5 & 6 & 7 & 8 & 9 & 10 & 11 & 12 & 13 & 14 \\
\hline \multicolumn{15}{|c|}{ Major and minor Oxides } \\
\hline $\mathrm{SiO}_{2}$ & 75.41 & 73.99 & 74.87 & 74.91 & 75.32 & 74.31 & 75.91 & 73.35 & 72.24 & 74.78 & 72.11 & 73.79 & 74.25 & 71.77 \\
\hline $\mathrm{TiO}_{2}$ & 0.12 & 0.19 & 0.83 & 1.11 & 1.23 & 1.25 & 0.71 & 0.91 & 0.87 & 1.21 & 1.89 & 0.93 & 1.23 & 1.11 \\
\hline $\mathrm{Al}_{2} \mathrm{O}_{3}$ & 13.92 & 13.78 & 12.96 & 13.63 & 12.23 & 13.29 & 13.49 & 13.91 & 14.21 & 11.97 & 15.21 & 13.11 & 14.19 & 12.92 \\
\hline $\mathrm{Fe}_{2} \mathrm{O}_{3}$ & 0.87 & 1.01 & 1.3 & 1.02 & 1.01 & 0.93 & 1.02 & 1.21 & 1.14 & 0.99 & 0.83 & 1.21 & 1.27 & 1.71 \\
\hline $\mathrm{FeO}$ & 0.21 & 0.29 & 0.31 & 0.31 & 0.39 & 0.31 & 0.39 & 0.21 & 0.41 & 0.35 & 0.29 & 0.39 & 0.29 & 0.32 \\
\hline $\mathrm{MnO}$ & 0.07 & 0.09 & 0.08 & 0.08 & 0.07 & 0.08 & 0.1 & 0.08 & 0.09 & 0.07 & 0.09 & 0.07 & 0.07 & 0.06 \\
\hline $\mathrm{MgO}$ & 0.09 & 0.09 & 0.89 & 0.11 & 0.71 & 0.12 & 0.09 & 0.08 & 0.13 & 0.14 & 0.13 & 0.09 & 0.08 & 0.11 \\
\hline $\mathrm{CaO}$ & 1.67 & 1.41 & 1.39 & 1.41 & 1.51 & 1.39 & 1.47 & 1.52 & 1.22 & 1.15 & 1.71 & 1.66 & 1.37 & 1.54 \\
\hline $\mathrm{Na}_{2} \mathrm{O}$ & 3.65 & 4.29 & 3.84 & 3.28 & 3.99 & 3.91 & 3.71 & 2.87 & 3.64 & 3.79 & 2.11 & 3.81 & 3.44 & 3.79 \\
\hline $\mathrm{K}_{2} \mathrm{O}$ & 4.68 & 4.93 & 3.91 & 3.89 & 4.11 & 4.91 & 4.51 & 4.29 & 5.35 & 4.67 & 3.79 & 4.71 & 4.71 & 5.11 \\
\hline $\mathrm{P}_{2} \mathrm{O}_{5}$ & 0.05 & 0.03 & 0.04 & 0.03 & 0.04 & 0.04 & 0.07 & 0.03 & 0.05 & 0.03 & 0.04 & 0.02 & 0.01 & 0.04 \\
\hline $\mathrm{H}_{2} \mathrm{O}$ & 1.23 & 0.78 & 0.89 & 1.11 & 0.91 & 1.3 & 1.21 & 1.11 & 0.93 & 1.21 & 1.31 & 1.15 & 0.78 & 0.85 \\
\hline \multicolumn{15}{|c|}{ Trace elements } \\
\hline $\mathrm{Ba}$ & 359 & 348 & 254 & 278 & 451 & 412 & 254 & 354 & 265 & 458 & 126 & 278 & 297 & 378 \\
\hline $\mathrm{Rb}$ & 68 & 61 & 59 & 57 & 46 & 72 & 57 & 95 & 76 & 24 & 49 & 61 & 58 & 49 \\
\hline $\mathrm{Sr}$ & 394 & 361 & 294 & 189 & 275 & 287 & 345 & 267 & 178 & 194 & 97 & 310 & 290 & 318 \\
\hline $\mathrm{Ga}$ & 12 & 10 & 17 & 8 & 11 & 10 & 15 & 17 & 10 & 13 & 19 & 10 & 12 & 18 \\
\hline $\mathrm{Nb}$ & 15 & 9 & 11 & 18 & 10 & 14 & 12 & 11 & 11 & 18 & 10 & 13 & 17 & 11 \\
\hline
\end{tabular}




\begin{tabular}{|c|c|c|c|c|c|c|c|c|c|c|c|c|c|c|}
\hline $\mathrm{Zr}$ & 160 & 178 & 125 & 101 & 124 & 146 & 179 & 156 & 90 & 160 & 105 & 89 & 103 & 141 \\
\hline $\mathrm{Y}$ & 16 & 17 & 13 & 16 & 17 & 9 & 15 & 17 & 6 & 12 & 11 & 17 & 10 & 8 \\
\hline Th & 6 & 7 & 8 & 1 & 5 & 1 & 5 & 7 & 2 & 3 & 4 & - & - & 5 \\
\hline $\mathrm{U}$ & 4 & 3.1 & 2.3 & 2.1 & 2 & 2 & 1 & 2.1 & 2.4 & 1 & 2.1 & 2.4 & 2.1 & 2 \\
\hline $\mathrm{Ni}$ & 57 & 26 & 24 & 19 & 22 & 34 & 47 & 58 & 49 & 57 & 34 & 21 & 29 & 45 \\
\hline $\mathrm{Cu}$ & 12 & 10 & 16 & 24 & 27 & 11 & 18 & 13 & 15 & 9 & 22 & 24 & 31 & 15 \\
\hline $\mathrm{V}$ & 37 & 39 & 75 & 49 & 42 & 76 & 58 & 49 & 37 & 57 & 67 & 69 & 53 & 54 \\
\hline $\mathrm{Zn}$ & 67 & 62 & 60 & 64 & 81 & 58 & 64 & 36 & 49 & 57 & 53 & 62 & 57 & 49 \\
\hline $\mathrm{La}$ & 15 & 13 & 17 & 11 & 12 & 17 & 19 & 8 & 14 & 19 & 16 & 11 & 14 & 10 \\
\hline $\mathrm{Ce}$ & 22 & 24 & 29 & 38 & 39 & 29 & 50 & 22 & 27 & 38 & 34 & 39 & 29 & 33 \\
\hline $\mathrm{Nd}$ & 13 & 10 & 17 & 14 & 10 & 22 & 18 & 27 & 10 & 26 & 24 & 13 & 18 & 10 \\
\hline
\end{tabular}

Table 2. Major oxides and trace elements of gabbroic rocks, Um Had area

\begin{tabular}{|c|c|c|c|c|c|c|c|c|c|c|c|c|c|c|}
\hline & \multicolumn{14}{|c|}{ Gabbros } \\
\hline & 1 & 2 & 3 & 4 & 5 & 6 & 7 & 8 & 9 & 10 & 11 & 12 & 13 & 14 \\
\hline \multicolumn{15}{|c|}{ Major and minor Oxides } \\
\hline $\mathrm{SiO}_{2}$ & 52.3 & 48.91 & 50.11 & 48.39 & 46.49 & 49.1 & 50.21 & 48.34 & 49.97 & 51.21 & 45.83 & 50.39 & 50.77 & 47.52 \\
\hline $\mathrm{TiO}_{2}$ & 1.84 & 1.97 & 0.44 & 1.23 & 1.24 & 1.73 & 0.97 & 1.34 & 1.92 & 0.87 & 1.23 & 1.11 & 1.01 & 0.97 \\
\hline $\mathrm{Al}_{2} \mathrm{O}_{3}$ & 17.49 & 18.11 & 17.29 & 17.22 & 14.13 & 17.97 & 15.32 & 15.21 & 14.93 & 17.14 & 15.73 & 17.29 & 17.91 & 18.21 \\
\hline $\mathrm{FeO}\{\mathrm{t}$ & 10.28 & 11.91 & 13.41 & 12.91 & 14.12 & 10.19 & 15.42 & 16.13 & 12.83 & 11.14 & 14.91 & 10.11 & 11.37 & 11.93 \\
\hline $\mathrm{MnO}$ & 0.19 & 0.17 & 0.19 & 0.14 & 0.19 & 0.15 & 0.71 & 0.17 & 0.13 & 0.17 & 0.13 & 0.19 & 0.18 & 0.16 \\
\hline $\mathrm{MgO}$ & 4.89 & 4.74 & 5.21 & 6.13 & 6.19 & 5.32 & 4.14 & 4.93 & 5.21 & 4.87 & 5.32 & 6.17 & 5.17 & 5.91 \\
\hline $\mathrm{CaO}$ & 8.74 & 10.12 & 8.16 & 10.11 & 13.21 & 9.71 & 10.31 & 8.81 & 12.14 & 10.71 & 11.87 & 10.74 & 10.97 & 11.43 \\
\hline $\mathrm{Na}_{2} \mathrm{O}$ & 2.41 & 3.15 & 2.79 & 3.14 & 3.19 & 2.79 & 2.14 & 3.14 & 3.19 & 2.87 & 3.14 & 2.88 & 2.78 & 2.49 \\
\hline $\mathrm{K}_{2} \mathrm{O}$ & 0.87 & 1.01 & 0.94 & 0.49 & 1.11 & 0.91 & 0.94 & 0.79 & 0.83 & 0.79 & 0.96 & 0.81 & 0.78 & 0.32 \\
\hline $\mathrm{P}_{2} \mathrm{O}_{5}$ & 0.88 & 0.54 & 0.63 & 0.72 & 0.79 & 0.64 & 0.53 & 0.43 & 0.75 & 0.83 & 0.79 & 0.44 & 0.79 & 0.83 \\
\hline Total & 99.89 & 100.4 & 99.17 & 100.5 & 100.7 & 98.51 & 100.7 & 99.29 & 101.9 & 100.6 & 99.91 & 100.1 & 101.7 & 99.77 \\
\hline \multicolumn{15}{|c|}{ Trace elements } \\
\hline $\mathrm{Ba}$ & 340 & 533 & 371 & 410 & 513 & 618 & 344 & 579 & 430 & 520 & 290 & 330 & 441 & 598 \\
\hline $\mathrm{V}$ & 120 & 331 & 211 & 140 & 190 & 180 & 182 & 230 & 214 & 419 & 310 & 170 & 179 & 176 \\
\hline $\mathrm{Cr}$ & 23 & 30 & 18 & 8 & 12 & 21 & 4 & 18 & 21 & 53 & 27 & 18 & 10 & 9 \\
\hline $\mathrm{Co}$ & 19 & 39 & 51 & 40 & 33 & 52 & 43 & 31 & 37 & 39 & 42 & 34 & 33 & 27 \\
\hline $\mathrm{Ni}$ & 14 & 53 & 49 & 32 & 28 & 19 & 17 & 39 & 29 & 40 & 31 & 34 & 18 & 19 \\
\hline $\mathrm{Cu}$ & 13 & 19 & 25 & 12 & 33 & 37 & 41 & 32 & 11 & 16 & 21 & 17 & 31 & 26 \\
\hline $\mathrm{Zn}$ & 109 & 104 & 93 & 117 & 129 & 150 & 139 & 128 & 112 & 120 & 129 & 129 & 137 & 81 \\
\hline $\mathrm{Ga}$ & 19 & 16 & 20 & 22 & 14 & 19 & 23 & 16 & 18 & 20 & 20 & 18 & 20 & 21 \\
\hline $\mathrm{Pb}$ & 8 & 9 & 3 & 1 & 4 & 9 & 3 & 2 & 9 & 3 & 1 & - & 3 & - \\
\hline $\mathrm{Rb}$ & 73 & 79 & 81 & 19 & 30 & 18 & 53 & 19 & 45 & 39 & 70 & 84 & 93 & 23 \\
\hline $\mathrm{Sr}$ & 674 & 607 & 699 & 739 & 930 & 579 & 599 & 737 & 719 & 761 & 589 & 289 & 609 & 847 \\
\hline Y & 31 & 34 & 12 & 19 & 25 & 31 & 39 & 40 & 35 & 23 & 26 & 34 & 20 & 27 \\
\hline $\mathrm{Zr}$ & 43 & 39 & 59 & 34 & 49 & 94 & 78 & 71 & 59 & 73 & 79 & 84 & 102 & 130 \\
\hline $\mathrm{Nb}$ & 14 & 18 & 29 & 15 & 12 & 15 & 27 & 6 & 15 & 30 & 14 & 21 & 32 & 15 \\
\hline $\mathrm{Ce}$ & 531 & 39 & 48 & 58 & 34 & 73 & 54 & 59 & 31 & 51 & 43 & 39 & 11 & 22 \\
\hline
\end{tabular}




\section{Results}

\subsection{Geochemistry of the Granitoids}

The Um Had granites reveal general decrease of major oxides $\left(\mathrm{TiO}_{2}, \mathrm{Al}_{2} \mathrm{O}_{3}, \mathrm{MgO}, \mathrm{Fe}_{2} \mathrm{O}_{3}\right.$ and $\left.\mathrm{CaO}\right)$ in relation with $\mathrm{SiO}_{2}$, which can be attributed to fractional crystallisation processes. These granitoid rocks can be classified by using normative An-Ab-Or ternary diagram of Barker (1979) and Q-ANOR of Streckeisen and Matiere, (1979), where all samples fall within the monzogranite field (Figures $2 \mathrm{a}$ and $2 \mathrm{~b}$ ). On the $\mathrm{Zr}$ versus $10^{4} \mathrm{Ga} / \mathrm{Al}$ binary diagram of Whalen et al. (1987), the studied samples fall within I \& S Type granites field (Figure 2c). Chappell and White (1974) used the Mol. $\mathrm{Al}_{2} \mathrm{O}_{3} /\left(\mathrm{CaO}+\mathrm{Na}_{2} \mathrm{O}+\mathrm{K}_{2} \mathrm{O}\right)$ ratio against $\mathrm{Rb} / \mathrm{Sr}$ ratio to differentiate between I-type and S-type granites. On this binary diagram (Figure 2d) all the studied granitoid samples fall within the I-type field, except one biotite granite sample lies at the boundary separating between the two fields of I-type and S-type granites. Moreover, White and Chappell (1983) as well as Liew et al. (1989) used the $\mathrm{Na}_{2} \mathrm{O}-\mathrm{K}_{2} \mathrm{O}$ binary diagram (Figure $3 \mathrm{a}$ ) to discriminate between I-type, S-type and T-type granites. Plots of the all granitoid samples lie in the I-type granite field indicating igneous source materials for the studied granites, except two biotite granite samples fall within the transition (T-type) field.

All plots of the investigated granitoids fall within the calc-alkaline field (Figure 3b) on the AFM ternary diagram of Irvine and Baragar (1971). Moreover, Petro et al. (1979) used the AFM ternary diagram to discriminate between compressional and extensional suites. Plots of the studied granitoids mostly have the trend of compressional suite. On the $\mathrm{SiO}_{2}$ vs. $\mathrm{K}_{2} \mathrm{O}$ diagram of Peccerillo and Taylor (1976), the studied granitoid samples fall within the field of high-K calc-alkaline series (Figure 3c).

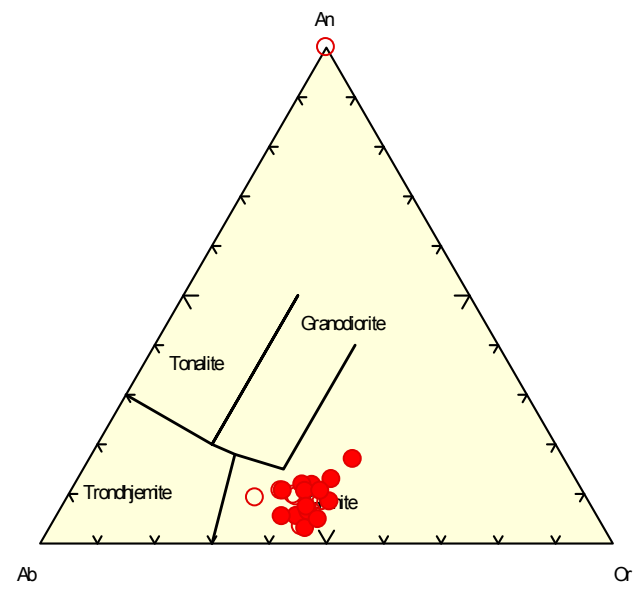

Figure 2a

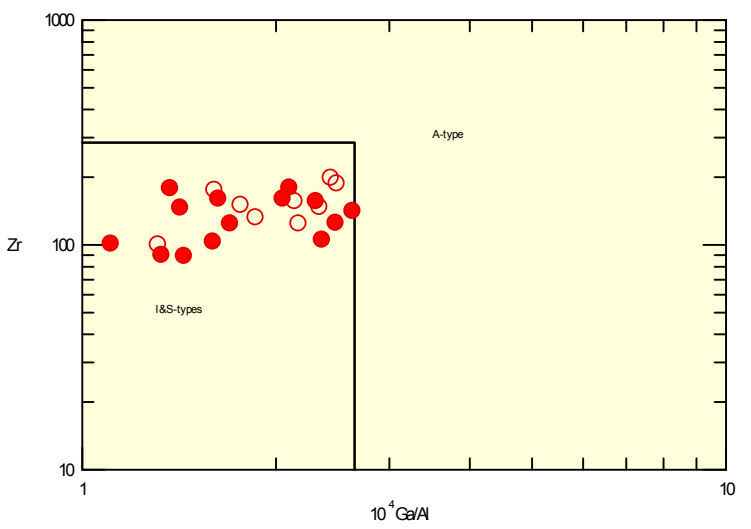

Figure 2c

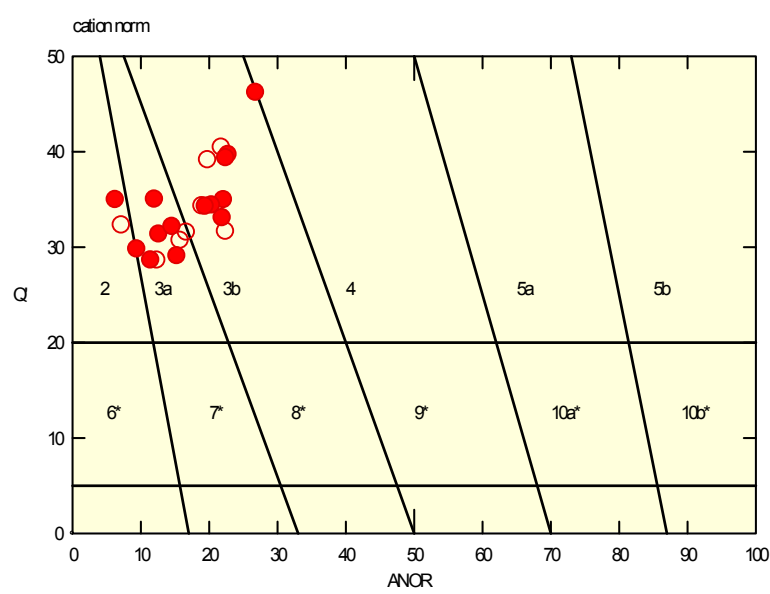

Figure $2 b$

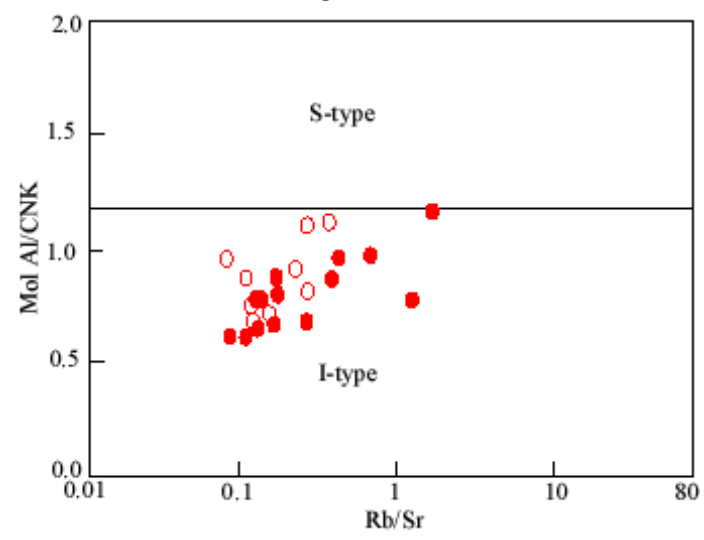

Figure 2d

Figure 2. Plots of the analyzed granitoid rocks on A) An-Ab-Or ternary diagram (after Barker, 1979), B) Q-ANOR diagram of Streckeisen and Matiere, (1979), C) $\mathrm{Zr}$ vs. $10^{4} \mathrm{Ga} / \mathrm{Al}$ diagram of of Whalen et al. (1987), D)

Mol. $\mathrm{Al}_{2} \mathrm{O}_{3} /\left(\mathrm{CaO}+\mathrm{Na}_{2} \mathrm{O}+\mathrm{K}_{2} \mathrm{O}\right)$ versus $\mathrm{Rb} / \mathrm{Sr}$ diagram (after Chappell and White, 1974) discriminating between I-type and S-type granites. Symbols: Filled red circles are biotite granite, while open circles are pink granite 
On the $\mathrm{Al}_{2} \mathrm{O}_{3} /\left(\mathrm{CaO}+\mathrm{Na}_{2} \mathrm{O}+\mathrm{K}_{2} \mathrm{O}\right)$ versus $\mathrm{Al}_{2} \mathrm{O}_{3} /\left(\mathrm{Na}_{2} \mathrm{O}+\mathrm{K}_{2} \mathrm{O}\right)$ binary diagram of Maniar and Piccoli (1989), all plots of these younger granites are of peraluminous to metaluminous nature (Figure 3d). Plots of studied granitoids on the $\mathrm{Y}$ vs. $\mathrm{Nb}$ and $\mathrm{Y}+\mathrm{Nb}$ vs. Rb binary diagrams (Figures 4a and 2b) of Pearce et al. (1984) reveal that these granites were formed within volcanic arc tectonic environment.

On the normative An-Ab-Or ternary diagram of Barker (1979) all plots of biotite granite and the two mica granite samples fall in a region of low to moderate water-vapour pressure ranging from 1 to $5 \mathrm{k}$-bars. Meanwhile, the biotite granites were emplaced under high temperature conditions, ranging from about 800 to $840{ }^{\circ} \mathrm{C}$, whereas the two mica granites were emplaced under moderate temperature conditions ranging from about 760 to $800{ }^{\circ} \mathrm{C}$ (Figure 4c). The Rb-Sr binary diagram (after Condie, 1973) shows that the Um Had granites have emplaced at relatively shallow to moderate depths between 20 and $30 \mathrm{~km}$ (Figure 4d).

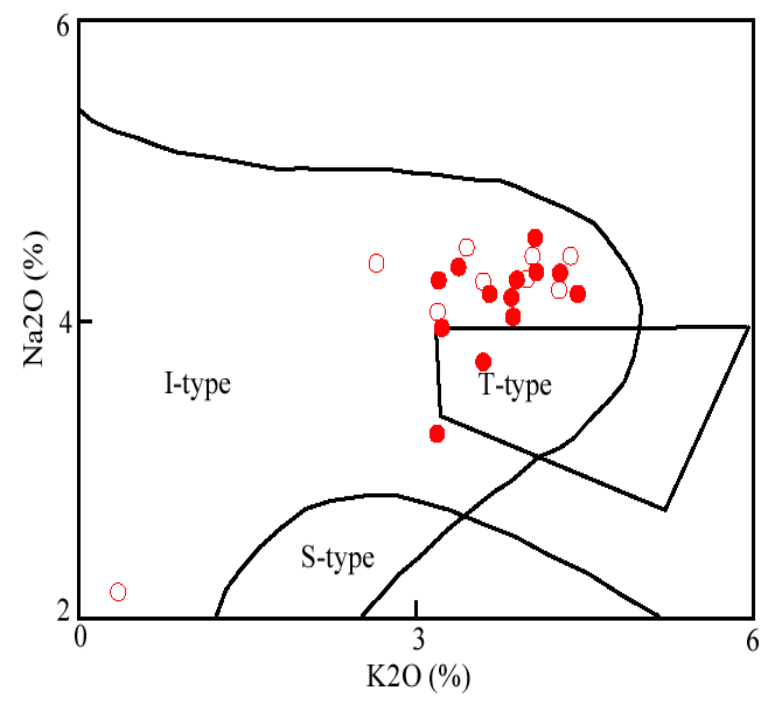

Figure $3 \mathrm{a}$

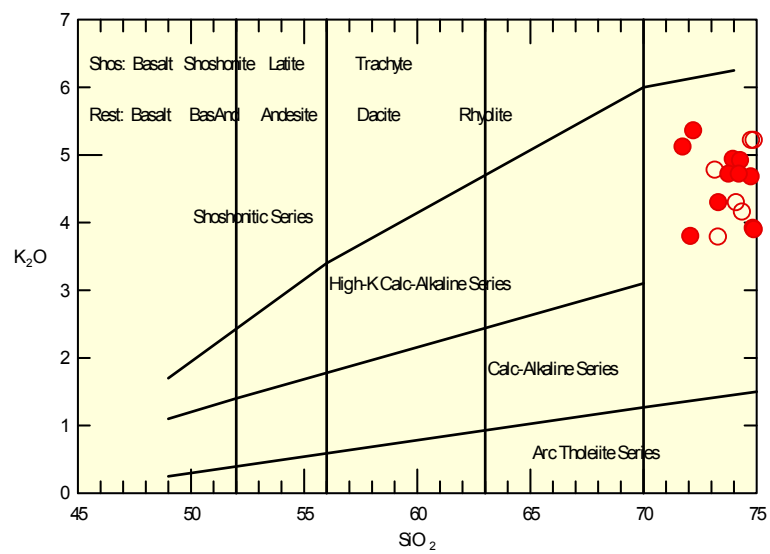

Figure $3 \mathrm{c}$

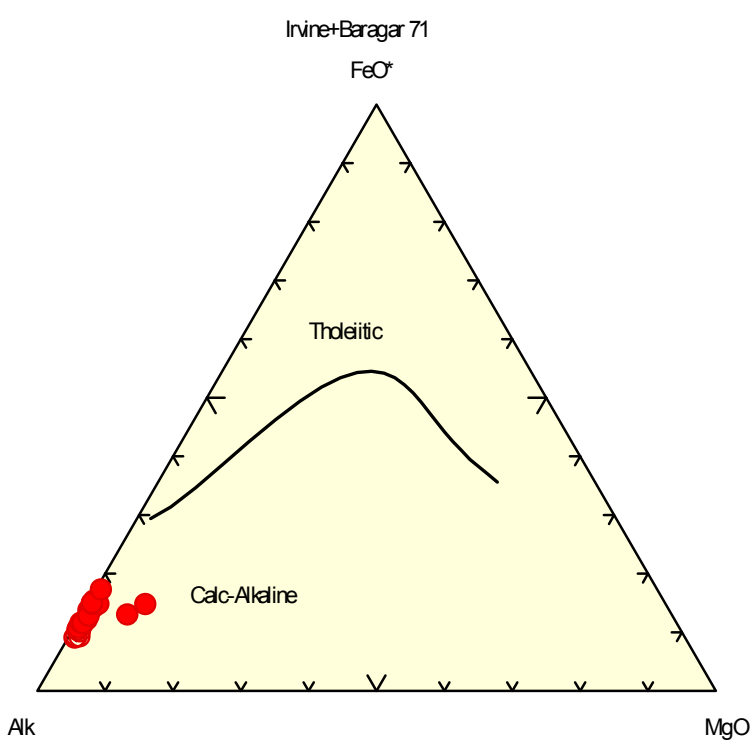

Figure $3 b$

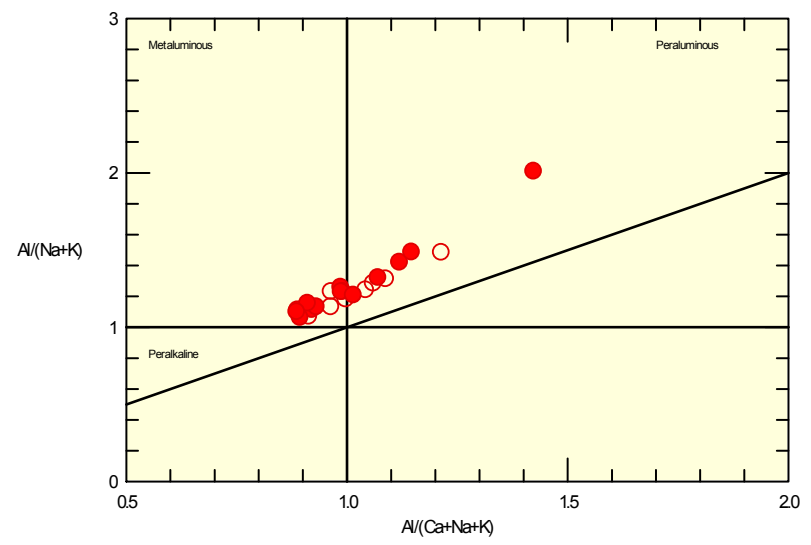

Figure 3d

Figure 3. Plots of the analyzed granitoid rocks on $\mathrm{A}$ ) The $\mathrm{Na}_{2} \mathrm{O}$ versus $\mathrm{K}_{2} \mathrm{O}$ binary diagram (after White and Chappell (1983), the T-type field after Liew et al. (1989)), b) AFM ternary diagram (Irvine \& Baragar, 1971), on C) $\mathrm{SiO}_{2}$ vs. $\mathrm{K}_{2} \mathrm{O}$ diagram (after Peccerillo and Taylor (1976)), D) $\mathrm{Al}_{2} \mathrm{O}_{3} /(\mathrm{CaO}+\mathrm{Na} 2 \mathrm{O}+\mathrm{K} 2 \mathrm{O})$ vs. $\mathrm{Al}_{2} \mathrm{O}_{3} /\left(\mathrm{Na}_{2} \mathrm{O}+\right.$ $\mathrm{K}_{2} \mathrm{O}$ ) diagram (after Maniar and Piccoli (1989))

\subsection{Geochemistry of the Gabbros}

The total alkalis vs. silica classification diagrams (after Le Bas et al., 1986; Cox et al., 1979) were used to classify the studied gabbros. All plots of gabbros fall within the basalt (gabbro) field (Figures 5a \& b). Plotting of the studied gabbros on $\mathrm{Na}_{2} \mathrm{O}+\mathrm{K}_{2} \mathrm{O}$ vs. $\mathrm{SiO}_{2}$ and $\mathrm{AFM}$ diagrams of Irvine and Baragar (1971) favors that these 
gabbros were derived from subalkaline magma (Figure 5c), with tholeiitic nature (Figure 5d). Also, on the $\mathrm{SiO}_{2}$ vs. $\mathrm{FeOt} / \mathrm{MgO}$ diagram of Miyashiro (1974) all the plotted samples of the different gabbroic members lie in the tholeiite field (Figure 5e).

There are two models that have been proposed for the geotectonic environment and magma sources of the younger gabbros. These are the tensional environment or rift-related (El Gaby et al., 1988; El-Mettwaly, 1992) and the subduction-related or island-arc environment (Mohamed \& Hassanen, 1996). On the AFM diagram, Petro et al. (1979) defined two tectonic trends discriminating between the compressional and extensional suites. The studied gabbros are concordant with the compressional trend indicating their origin in compressional environment (subduction-related or island-arc environment). Plots of the studied gabbros on the $\mathrm{Y}$ vs. $\mathrm{Cr}$ discrimination diagram (after Pearce, 1982) favor the arc-related tectonic setting for these gabbros, where all plots of gabbros fall within the field of volcanic-arc basalts (Figure 5f).

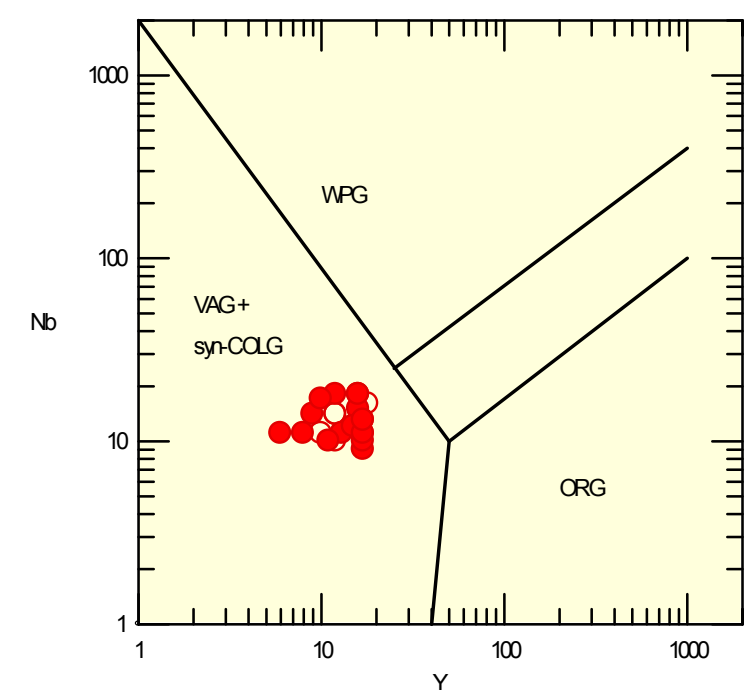

Figure $4 \mathrm{a}$

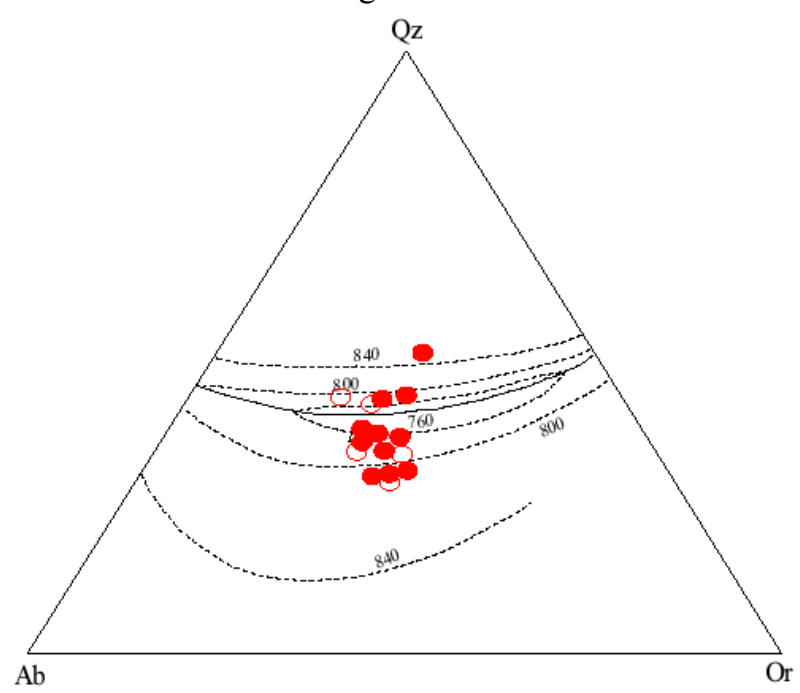

Figure 4c

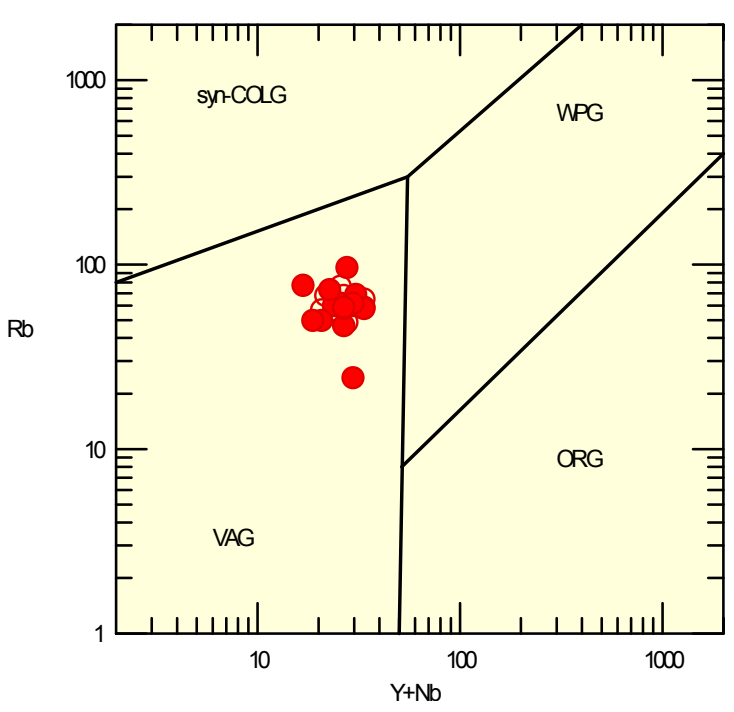

Figure 4b

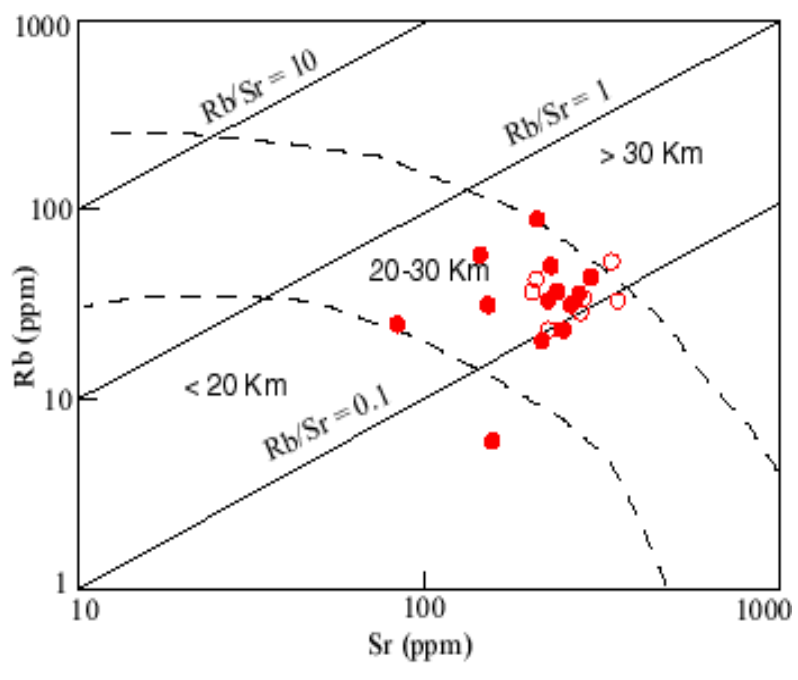

Figure 4d

Figure 4. Plots of Um Had granitoids A) Y vs. Nb diagram (after Pearce et al., 1984), B) Y+Nb vs. Rb diagram (after Pearce et al., 1984), C) Q-Ab-Or normative diagram (after Barker, 1979), D) SR vs. Rb binary diagram (after Condie, 1973) 


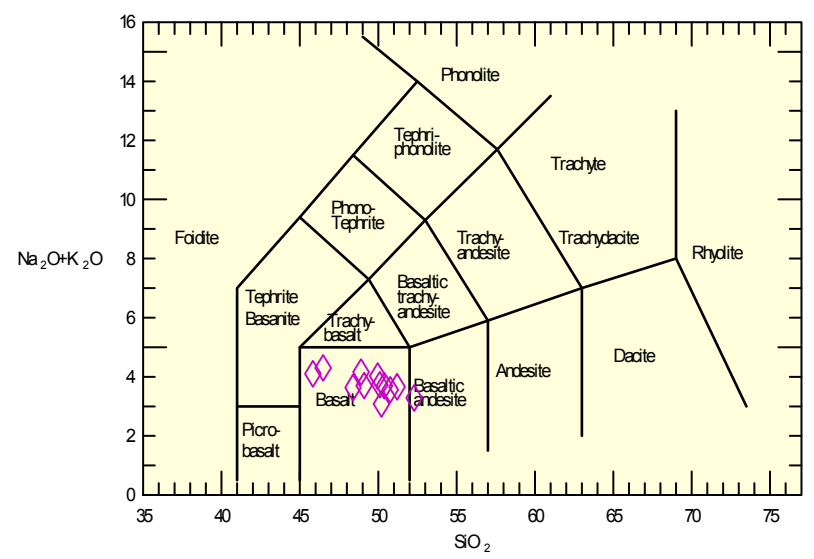

Figure 5a

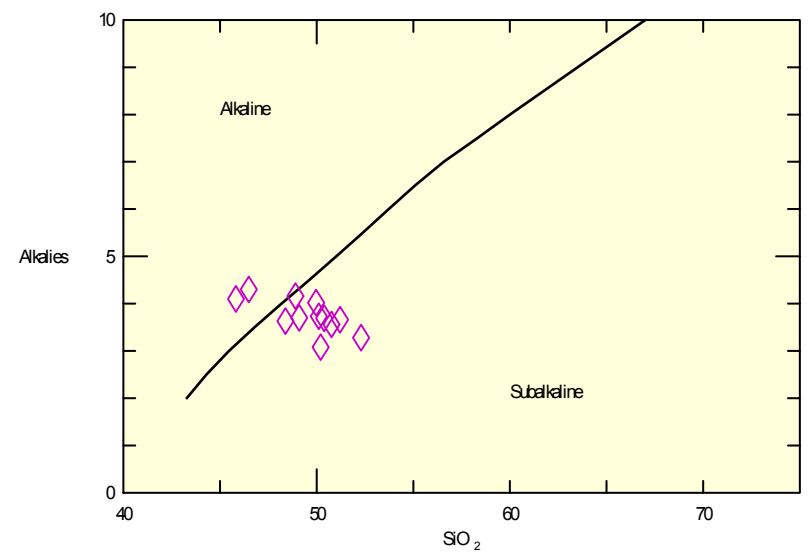

Figure 5c

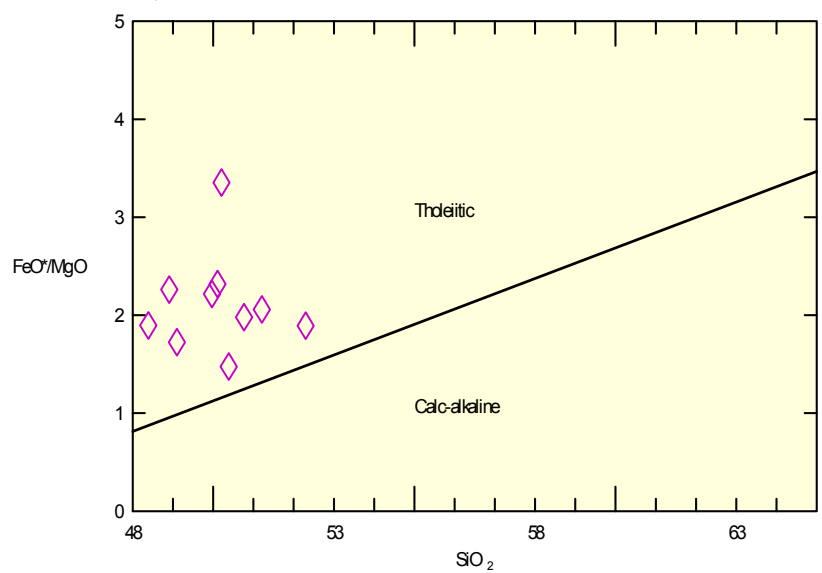

Figure 5e

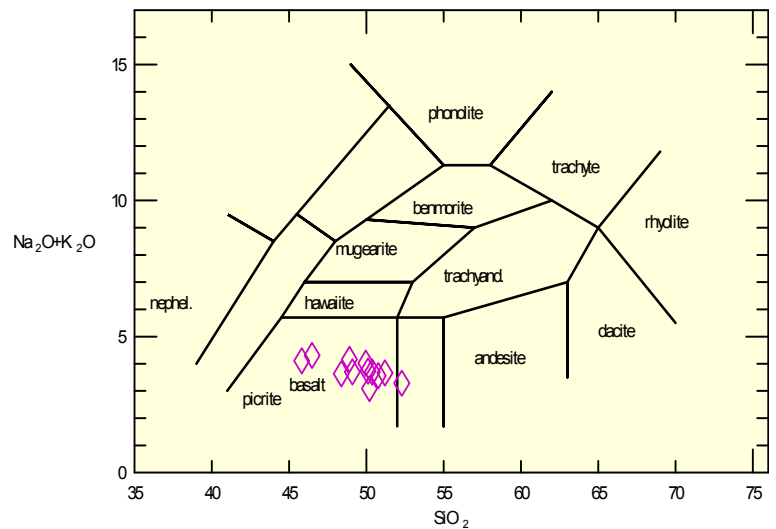

Figure $5 b$

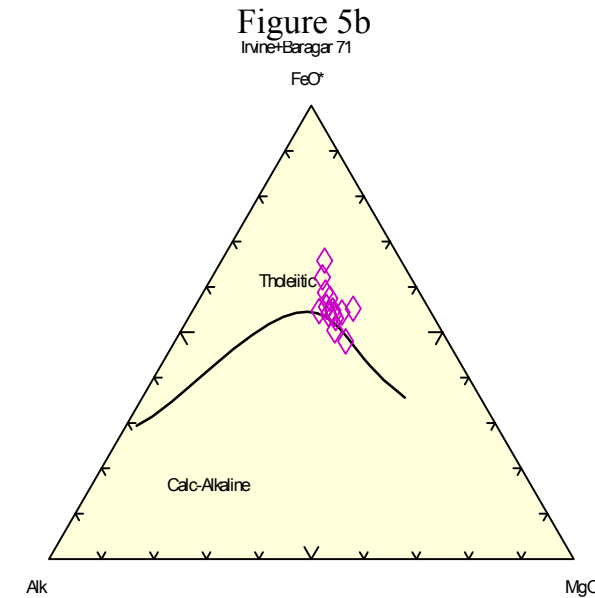

Figure 5d

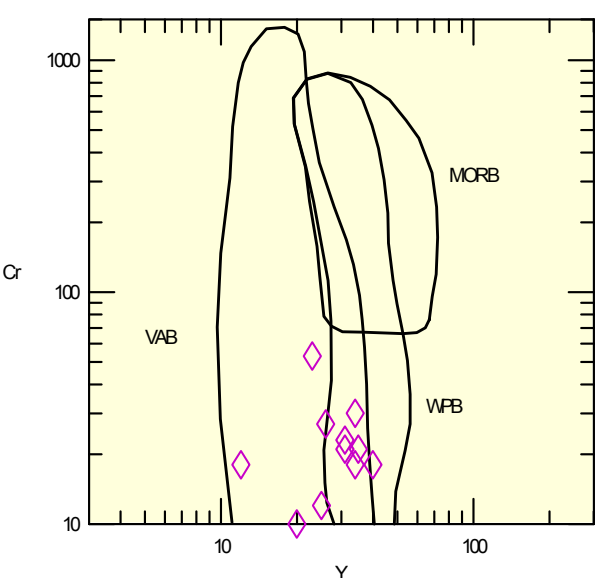

Figure $5 f$

Figure 5. Plots of the studied gabbros on A) TAS classification diagram (after Le Bas et al., 1986), B) TAS classification diagram (after Cox et al. 1979), C) $\mathrm{SiO}_{2}$ vs. $\mathrm{Na}_{2} \mathrm{O}+\mathrm{K}_{2} \mathrm{O}$ diagram (after Irvine and Baragar, 1971),

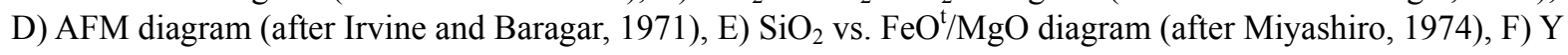
vs. Cr diagram (after Pearce et al., 1982)

\section{Summery and Conclusions}

The late to post-tectonic granites of Um Had area are typically monzogranites (biotite granites and biotite-muscovite granites). They have calc-alkaline, metaluminous to slightly peraluminous nature and potassic affinity. Both biotite-granites and biotite-muscovite granites have emplaced during late-orogenic regime in compressional suite. They were formed under relatively low to moderate water-vapour pressure (1-5 k-bars) at 
moderate depths $(20-30 \mathrm{~km})$. Biotite granites were formed under relatively high temperature range $\left(800-840{ }^{\circ} \mathrm{C}\right)$, while biotite-muscovite granites were formed under relatively moderate temperature conditions $\left(760-800{ }^{\circ} \mathrm{C}\right)$. The gabbros have been derived from subalkaline basic magma exhibiting tholeiitic nature. They were emplaced in compressional subduction-related environment having characters of the island-arc and active continental margin. Although caution is required in using the tectonic setting discrimination diagrams (Verma, 2010), results and graphical plots of the investigated rocks seem reasonable and convincing. It is therefore, concluded that island arc gabbros might have sourced the late subduction-related calc-alkaline granitoids are the convergent plate setting was long prevailed during the waning stages of the pan-African orogeny.

\section{Acknowledgements}

Special thanks should go to Drs. Ashraf Emam (Aswan Univ., Egypt) and Basem Zoheir (Benha Univ., Egypt) for their immense help in undertaking this work. Prof. G. Kamal el-Din (South Valley Univ., Egypt) is acknowledged for suggesting the point and help in making the geochemical analysis possible.

\section{References}

Abdel-Rahman, A. F. M., \& Doig, R. (1987). The Rb-Sr geochronological evolution of the Ras Gharib segment of the northern Nubian Shield. Journal of the Geological Society, 144(4), 577-586. http://dx.doi.org/10.1144/gsjgs.144.4.0577

Barker, F. (1979). Trondhjemites: definition, environment and hypotheses of origin. In F. Barker (Ed.), trondhjemites, dacites and related rocks (pp. 1-12), Elsevier, Amsterdam. http://dx.doi.org/10.1016/B978-0-444-41765-7.50006-X

Bickford, M. E., Sultan, M., Arvidson, R. E., \& El-Kaliouby, B. (1989). Evidence for involvement of pre-Late Proterozoic crust in the Nubian Shield, Egypt: Common Pb data from K-feldspars. Geol Soc Am (Abs), 21, A24.

Black, R., \& Liegeois, J. P. (1993): Cratons, mobile belts, alkaline rocks and continental lithospheric mantle: the Pan-African testimony. Journal Geological Society London, 150, 89-98. http://dx.doi.org/10.1144/gsjgs.150.1.0088

Breitkreuz, C., Eliwa, H., Khalaf, I., El Gameel, K., Bühler, B., Sergeev, S., ... \& Murata, M. (2010). Neoproterozoic SHRIMP U-Pb zircon ages of silica-rich Dokhan Volcanics in the northeasternDesert. Egypt. Precambrian Research, 182, 163-174. http://dx.doi.org/10.1016/j.precamres.2010.06.019

Chappell, B. W., \& White, A. J. R. (1974). Two contrasting granite types. Pacific Geol., 8, 173-174.

Condie, K. C. (1973). Archean magmatism and crustal thickening. Geol. Soc. Amer. Bull., 84, 2981-2992. http://dx.doi.org/10.1130/0016-7606(1973)84<2981:AMACT>2.0.CO;2

Cox, K. G., Bell, J. D., \& Pankhurst, R. J. (1979). The Interpretation of Igneous Rocks. Allen and Unwin, London. http://dx.doi.org/10.1007/978-94-017-3373-1

El Gaby, S., List, F. X., \& Tehrani, R. (1988). Geology, evolution and metallogenesis of the Pan-African Belt in Egypt. In S. El Gaby \& R. O. Greiling (Eds.), The Pan African Belt of Northeast Africa and adjacent areas. Tectonic Evolution and Economic Aspects of a Late Proterozoic Orogen (pp. 17-68). Earth Evolution Sciences, Frieder Vieweg and Sohn, Braunschweing/Wiesbaden.

El-Mettwaly, A. (1992). Pan-African post-orogenic gabbro cumulates from Sinai massif, Egypt: geochemistry and mineral chemistry. J. African Earth Sci., 14(2), 217-255. http://dx.doi.org/10.1016/0899-5362(92)90099-X

El-Sayed, M. M. (1998). Tectonic setting and petrogenesis of the Khadabora pluton: a Late Proterozoic anorogenic A-type younger granitoid in the Egyptian Shield. Chemie der Erde-Geochemistry, 58, 38-63.

El-Sayed, M. M., Mohamed, F. H., Furnes, H., \& Kanisawa, S. (2002). Geochemistry and petrogenesis of the Neoproterozoic granitoids in the Central Eastern Desert, Egypt. Chemie der Erde-Geochemistry, 62(4), 317-346. http://dx.doi.org/10.1078/0009-2819-00010

Fowler, T. J. (2001). Pan-African granite emplacement mechanisms in the Eastern Desert, Egypt. J. Afri. Earth Sci., 32, 61-86. http://dx.doi.org/10.1016/S0899-5362(01)90019-3

Gillespie, J. G., \& Dixon, T. H. (1983). Lead isotope systematics of some igneous rocks from the Egyptian Shield. Precambrian Res., 20, 63-77. http://dx.doi.org/10.1016/0301-9268(83)90029-3

Harris, N. B. W., \& Marriner, G. F. (1980). Geochemistry and petrogenesis of a peralkaline granite complex from 
the Midian Mountains, Saudi Arabia. Lithos, 13, 325-337. http://dx.doi.org/10.1016/0024-4937(80)90052-3

Hashad, A. H. (1980). Present status of geochronological data on the Egyptian basement complex. Bull Inst. Appl. Geol. (Jeddah), 3, 31-46. http://dx.doi.org/10.1016/B978-0-08-024479-2.50007-9

Irvine, T. N., \& Baragar, W. R. A. (1971). A guide to the chemical classification of the common volcanic rocks. Canadian Journal of Earth Sciences, 8, 523-548. http://dx.doi.org/10.1139/e71-055

Kröner, A., Todt, W., Hussein, I. M., Mansour, M., \& Rashwan, A. A. (1992). Dating of late Proterozoic ophiolites in Egypt and the Sudan using the single zircon evaporation technique. Precambrian Research, 59, 15-32. http://dx.doi.org/10.1016/0301-9268(92)90049-T

Le Bas, M. J., Le Maitre, R. W., Streckeisen, A., \& Zanetin, B. (1986). A chemical classification of volcanic rocks based on the total alkali-silica diagram. Journal of Petrology, 27, 745-750. http://dx.doi.org/10.1093/petrology/27.3.745

Liew, T., Finger, F., \& Hock, V. (1989). The molybdenum granitoid plutons of Austria chemical isotropic studies bearing on their environmental setting. Chem. Geol., 76, 41-55. http://dx.doi.org/10.1016/0009-2541(89)90126-5

Maniar, P. D., \& Piccoli, P. M. (1989). Tectonic discrimination of granitoids. Geol. Soc. Am. Bull., 101, 635-643. http://dx.doi.org/10.1130/0016-7606(1989)101<0635:TDOG $>2.3 . C O ; 2$

Miyashiro, A. (1974). Volcanic rock series in island arcs and active continental margins, American Journal of Science, 274, 321-355. http://dx.doi.org/10.2475/ajs.274.4.321

Mogahzi, A. M. (1999). Magma source and evolution of Late Neoproterozoic granitoids of Gabal El-Urf area, Eastern Desert, Egypt: geochemical and Sr-Nd isotopic constraints. Geological Magazine, 136(3), 285-300. http://dx.doi.org/10.1017/S0016756899002563

Mohamed, F. H., \& Hassanen, M. A. (1996). Geochemical evolution of arc-related mafic plutons in the Umm Naggat district, Eastern Desert of Egypt. J. African Earth Sci., 22, 269-283. http://dx.doi.org/10.1016/0899-5362(96)00018-8

Moussa, E. M. M., Stern, R. J., Manton, W. I., \& Ali, K. A. (2008). SHRIMP zircon dating and Sm/Nd isotopic investigations of Neoproterozoic granitoids, Eastern Desert, Egypt. Precambrian Research, 160, 341-356. http://dx.doi.org/10.1016/j.precamres.2007.08.006

Pearce, J. A. (1982). Trace element characteristics of lavas from destructive plate boundaries. In R. S. Thorpe (Ed.), Andesites, Orogenic andesites and Related Rocks (pp. 525-548), John Wiley \& Sons, Chichester.

Pearce, J. A., Harris, N. B. W., \& Tindle, A. G. (1984). Trace element discrimination diagrams for the tectonic interpretation of granitic rocks. Journal of Petrology, 25, 959-983. http://dx.doi.org/10.1093/petrology/25.4.956

Peccerillo, A., \& Taylor, S. R. (1976). Geochemistry of Eocene calc-alkaline volcanic rocks from the Kastamonu area, northern Turkey. Contributions to mineralogy and petrology, 58(1), 63-81. http://dx.doi.org/10.1007/BF00384745

Petro, W. L., Vogel, T. A., \& Wilband, J. T. (1979). Major element chemistry of plotunic suites from compressional and extensional plate boundaries. Chem. Geol., 26, 217-235. http://dx.doi.org/10.1016/0009-2541(79)90047-0

Rogers, J. J. W., \& Greenberg, J. K. (1981). Trace elements in continental margin magmatism: Part 3- alkali granites and their relationship to cratonisation. Geol Soc Am Bull, 92, 6-9. http://dx.doi.org/10.1130/0016-7606(1981)92<6:TEICMP>2.0.CO;2

Stern, R. J. (1981). Petrogenesis and tectonic setting of Late Precambrian ensimatic volcanic rocks, central Eastern Desert of Egypt. Precamb. Res., 16, 195-230. http://dx.doi.org/10.1016/0301-9268(81)90013-9

Stern, R. J., \& Gottfried, D. (1986). Petrogenesis of late Precambrian (575-600 Ma) bimodal suite in northeast Africa. Contrib. Mineral Petrol., 92, 492-501. http://dx.doi.org/10.1007/BF00374431

Stern, R. J., \& Hedge, C. E. (1985). Geochronologic and isotopic constraints on late Precambrian crustal evolution in the Eastern Desert of Egypt. Am. J. Sci., 258, 97-127. http://dx.doi.org/10.2475/ajs.285.2.97

Streckeisen, A., \& le Maitre, R. W. (1979). A chemical approximation to the modal QAPF classification of the igneous rocks. Neues Jarbuch Mineralogie, Abhandlungen, 136, 169-206.

Sultan, M., Chamberlain, K. R., Bowring, S. A., Arvidson, R. E., Abuzied, H., \& El Kaliouby, B. (1990). 
Geochronological and isotopic evidence for involvement of pre-Pan-African crust in the Nubian Shield, Egypt. Geology, 18, 761-764. http://dx.doi.org/10.1130/0091-7613(1990)018<0761:GAIEFI>2.3.CO;2

Verma, S. P. (2010). Statistical evaluation of bivariate, ternary and discriminant function tectonomagmatic discrimination diagrams. Turkish Journal of Earth Sciences, 19, 185-238.

Whalen, J. B., Currie, K. L., \& Chappel, B. W. (1987). A-type granites: geochemical characteristics, discrimination and petrogenesis. Contrib. Mineral Petrol., 95, 407-419. http://dx.doi.org/10.1007/BF00402202

White, A. J. R., \& Chappell, B. W. (1983). Granitoid types and their distribution in the Lachalan fold belt, Southeastern Australia. Geol. Soc. Am. Mem., 159, 21-34. http://dx.doi.org/10.1130/MEM159-p21

Wilde, S. A., \& Youssef, K. (2000). Significance of SHRIMP U-Pb dating of the Imperial Porphyry and associated Dokhan Volcanics, Gebel Dokhan, N Eastern Desert, Egypt. J. of Afri Earth Sci., 31, 410-413. http://dx.doi.org/10.1016/S0899-5362(00)00096-8

Wilde, S. A., \& Youssef, K. (2002). A re-evaluation of the origin and setting of the Late Precambrian Hammamat Group based on SHRIMP U-Pb dating of detrital zircons from Gebel Umm Tawat, North Eastern Desert, Egypt. J. Geol. Soc., London, 159, 595-604. http://dx.doi.org/10.1144/0016-764901-081

Willis, K. M., Stern, R. J., \& Clauer, N. (1988). Age and geochemistry of late Precambrian sediments of Hammamat series from the north of Eastern Desert of Egypt. Precambrian Research, 42, 173-187. http://dx.doi.org/10.1016/0301-9268(88)90016-2

\section{Copyrights}

Copyright for this article is retained by the author(s), with first publication rights granted to the journal.

This is an open-access article distributed under the terms and conditions of the Creative Commons Attribution license (http://creativecommons.org/licenses/by/3.0/). 